\title{
A Study on Nexus Between Reinsurance Dependency and Profitability in Ethiopian Insurance Sector with Special Reference to Property and Causality insurance
}

\author{
Gemachis Debala Biru \\ College of Business and Economics, Assosa University, PO box. 18, Assosa, Benishangul Gumuz, Ethiopia
}

\begin{abstract}
This study intends to investigate the nexus between reinsurance dependency and profitability in Ethiopian insurance sector with special reference to Property and Causality insurance on basis of data covers six years (20112016) period. The study selected sample of twelve (12) insurance companies to investigate them for six consecutive years (2011-2016) with total of 72 observations through panel data. Accordingly, the study used documentary analysis of companies' audited financial statements for general insurers which obtained from National Bank of Ethiopia and head office of each insurance companies. The reinsurance dependence is considered as an explanatory variable and its influence on profitability measured by return on asset (ROA) from the prominent previous studies were considered as dependent variable. The OLS were tested and the residual was found to be free of Multicollinearity. The results of panel least square regression analysis indicate that reinsurance dependence has a negative and statistically significant relationship with general insurance companies' profitability. Based on this finding, the study suggests that, the management bodies of the insurance companies should give high attention on reducing the amount of premium ceded by the insurers since it will reduce the profitability by better internal control to achieve superior profitability.
\end{abstract}

Keywords: Property and Causality Insurance, Profitability, Reinsurance

DOI: $10.7176 /$ RJFA/11-21-04

Publication date: November $30^{\text {th }} 2020$

\section{Introduction}

In the current era, an insurance companies provide unique financial service to societies and economic activities as an intermediary as well as the risk bearer (Kugler and Ofgohi, 2005, Kihara, 2012 and Ndalu, 2015). But, their financial system is not developed well (Abebaw, 2014). Particularly, the insurance sector takes major part in economic growth and development by providing capital accumulation efficiency from the premium charged, reinforce monetary and investment activities by providing long-term funds for physical and social infrastructure (Cudiamat and siy, 2017 and Daare, 2016). The Property and Causality insurance (PCI) business environment responsible for risk transfer, indemnification and risk pooling functions whereas financial intermediation is reflected in the life insurance business (Kugler and Ofoghi, 2005 and Ndalu, 2017). Under an increment of high severity and potential losses, the insurers will insure the insured for that unfavorable damages and financial stresses through the reinsurance which is the basic future of property and casualty insurance (Alip and Wilcox, 2015). Reinsurance is an activity of accepting risks ceded by an insurance company (Kramaric and Galetic, 2013).

The insurers purchase reinsurance to protect themselves, reduce insolvency risk and increasing the capacity against the risks of averse above certain thresholds (Bresan, 2018 and Duloju and Ajemunigbohun, 2017). In order to responsible for this crucial function in their operation; the PCI must need to have trillions dollars of funds. According to Adebowale \& Adebayo (2018), the Property and Causality insurance companies perform relatively low because they rely heavily on reinsurance protection as their main source of risk management technique. Contrary to this, Duloju and Ajemunigbohun (2017) and Lee and Lee (2012) states that the insurers which have high performance and growth rate have low reinsurance transaction which reflect its relation underwriting risk and the capacity of the insurers. Thus, their profitability and financial soundness must need a primary concern to perform their function well (Sidhu and Verma, 2017). They insurance companies can't survive in long run under the current complex business world, without distinguishing the linkage between profitability and factors influence it (Borlea and Achim, 2010).

As per National Bank of Ethiopia report of (2016), the Ethiopian insurance sectors growth rate of revenue from gross premium of insurance sector exhibits decline over time. The amount of revenues collected from the general insurance was low in comparison to revenue collected from life insurance service. Most of Property and Causality insurance (PCI)) business have taken a hit on their profitability in the previous fiscal year. Unfortunately, this may occur due to high amount of premium ceded by property and casualty insurances. For instance, National insurance companies, Nile insurance companies and Nyala insurance companies have suffered net profit decline by $10.5 \%, 57 \%$ and $24 \%$, respectively in the year end of 2016 on their policies underwritten by non-life insurance business. Despite, Lion insurance companies, United insurance companies and Awash Insurance Companies are also report low amount of profit on their policies underwritten by the Property and Causality insurance business. 
But, few of them were profitable companies in the period of year-ago. As a whole the premium portfolio of insurance companies operating in Ethiopian were dominated by Property and Causality insurance, but more revenues are collected from the policies written by long-term insurance companies. Particularly, the Ethiopian insurance sector are also remains underdeveloped and they are targeted at the corporate market, focusing on Property and Causality insurance and almost 90 percent of the population does not have any type of formal insurance (Gieger and Moller, 2015). Therefore, this paper aimed to explore the nexus between reinsurance dependence and profitability of Property and Causality insurance companies in Ethiopia, by addressing main question: How was the profitability of general insurers affected by the firm reinsurance dependency of the firm?

\section{Literature Review}

An insurance is a contract under which one party accepts significant insurance risk from another party by agreeing to compensate the policyholder if a specified uncertain future event (the insured event) adversely affects the policyholder [IFRS, 4). An insurance is plummeting uncertainty of occurrence of an event (Sushma, 2012). It is a service provided financial benefit in favor of an individual, association or business in exchange for collected premiums that provides a benefit in case a risk occurs (Berteji and Hammami, 2016 and Sushma, 2012). Particularly, reinsurance is the activity which consist of accepting risks ceded by an insurance company or by another reinsurance company. The insurers are obliged to dispose of any risk in excess of its own risk-bearing capability on its own account through reinsurance with companies which conduct active reinsurance operations which mean insurance company must reinsure that portion of the risks accepted which, according to the table of maximum covers, exceed the shares in risk compensation (Krmaric and Galetic, 2013).

Generally, a few studies have been investigated on the on nexus between reinsurance dependency and profitability in different jurisdictions. For instance, in order to conduct this study, some of the literatures were taken from Pakistan, Kenya, India, Taiwan, Nigeria and other Europe countries for an intention of investigating the nexus between reinsurance dependence and non-life insurance business profitability. When coming back to context of Ethiopia, no researches are conducted in the how specifically the reinsurance dependence influence the profitability; particularly in general insurance. Despite, some of the previous researches that conducted in different jurisdiction as well as in Ethiopia have also documented inconsistent and controversial results on nexus between reinsurance dependence and profitability which measured by return on asset.

For instance, the studies conducted on the impact of reinsurance dependence on profitability of Property and Causality insurance companies indicate different result such as Burca, and Batrinca (2014) and Moro and Anderloni (2014) found positive insignificant relationship between reinsurance and ROA, Datu (2016) found positive significant relationship between profitability and reinsurance dependence, suggesting that the non-life insurance business with higher reinsurance significantly have higher profitability from their firm. However, the studies that conducted by Kozak (2011), Jovovic et.al., (2014), Lee and Lee (2012), Demis (2016), Asrat and Tesfahun (2016) and Lee (2014) found negative relationship between reinsurance dependency and profitability, suggesting that the property and causality insurance business who have higher reinsurance dependence report low profit in comparison to premium they received from the policyholders and asset they own. Therefore, in this study the negative relationship is anticipated for the relationship between profitability (ROA) and reinsurance dependence. Therefore, the researcher formulates its hypothesis as follows:

$\mathrm{Ho}_{2}$ : Reinsurance dependence is negatively related to profitability of in Ethiopian company's in Ethiopia.

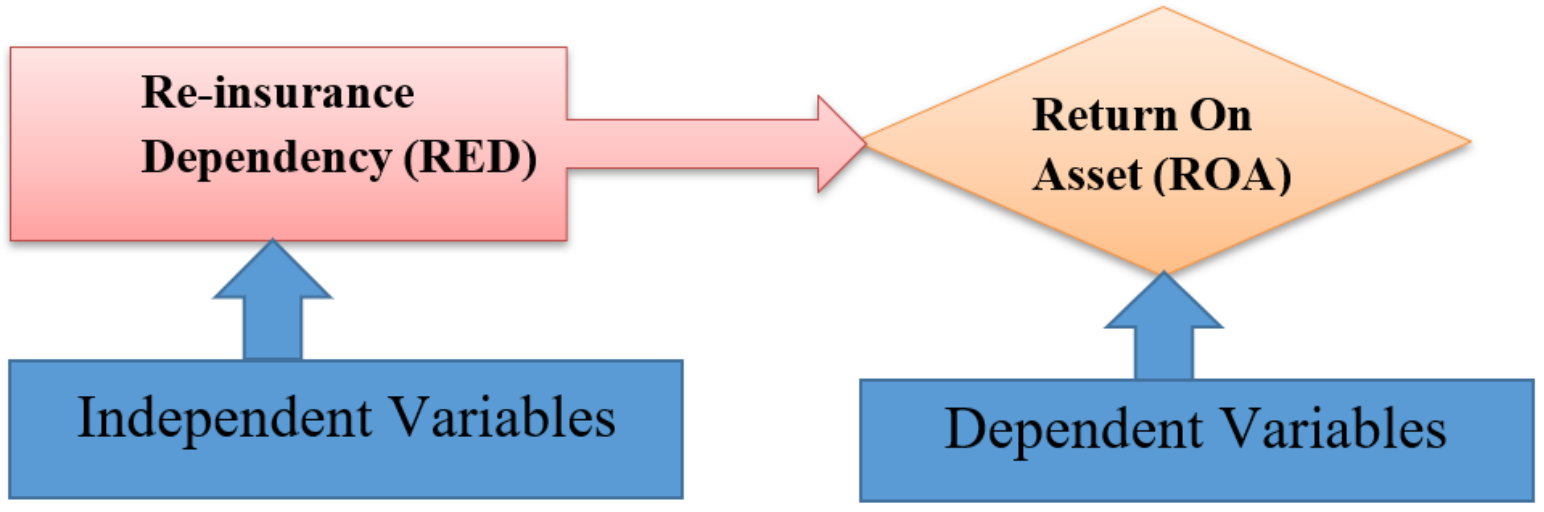

Figure 0.1: The Conceptual Framework or Model of the Study

\section{Methods}

The research work used the quantitative research approach based on the nature of data, the problem taken into account and pre-determined objective in this study. In context to the approach of the study, the study was based on positivist research paradigm philosophical assumption. The rationale for its engagement was due to the fact 
that, the study is commonly based on empirical observation, measurement and its deterministic in which cause determine the effects. The nature of research work and problem employed explanatory research design to explain the nexus between reinsurance dependence and profitability (Saunders et.al., 2016). For designing the sample, the National Bank of Ethiopia quarterly bulletin of 2017 which states 1 public and 16 private insurance companies with a total of 482 branches operating throughout the country. The target population of the current study employed all insurance companies operating in Ethiopia which have a license from NBE to underwrite a Property and Causality insurance business those have audited financial statements from 2011 to 2016. The study made use secondary data alone for six consecutive years (2010/2011 to 2015/16) from twelve insurance companies. It was used based on data that filed with publications of the National Bank of Ethiopia (NBE) and audited annual report of the firm. In addition to that, the researcher collected secondary data from books, previous journal article, research and from internet to explore and gather this published and archived data on the issues under investigation. To understand the nexus between reinsurance dependence and profitability of Property and Causality insurance companies operating in Ethiopia, the baseline regression model was developed which depending on the Adebowale \& Adebayo (2018); Aduloju \& Ajemunigbohun (2017); Mazviona et.al., 2017; Demis, 2016; Asrat and Tesfahun, 2016; Daare, 2016; Datu, 2016; Lee, 2014; Moro and Anderloni, 2014; Burca and Batrinca, 2014; Lee and Lee, 2012; and Kozak, 2011. The linear model which developed by the researcher is denoted as follows:

$$
\text { ROAit }=\alpha+\beta 1(\text { REDit })+C \text { it }
$$

\section{Results}

The research result presents the details of discussion on the nexus between reinsurance dependency and profitability of Property and Causality insurance companies are presented in table 1 below.

Table 1: Summary of descriptive statistics on relation between Reinsurance dependence and Profitability

\begin{tabular}{|l|l|l|}
\hline & ROA & RED \\
\hline Mean & 0.10 & 0.68 \\
\hline Median & 0.11 & 0.41 \\
\hline Maximum & 0.22 & 3.88 \\
\hline Minimum & -0.06 & 0.01 \\
\hline Std. Dev. & 0.05 & 0.69 \\
\hline Observations & 72 & 72 \\
\hline
\end{tabular}

Source: Output of Eviews 9

In table 1 above, the independent variable, reinsurance dependency (RED) have a mean value of 0.68 and standard deviation of 0.69 . The reinsurance dependence computed by dividing the premium ceded to total asset of the companies. This implies that on average $68 \%$ percent of the gross premium collected from the customers as percentage of total asset was ceded for the reinsurance purpose. On the other hand, the minimum and maximum value of 1 percent and 3.88 percent which indicate that, the minimum ratio of premium ceded shows lower risk of dependency on reinsurance whereas the higher premium ceded shows the higher risk of dependency on reinsurance sides.

Correlation analysis

As presented in table 2, the independent variable (Reinsurance Dependence) are correlated with profitability which is measured by ROA and it have lowest correlation coefficient.

Table 2: Correlation matrix of dependent and independent variable.

\begin{tabular}{|l|l|l|}
\hline & $R O A$ & $R E D$ \\
\hline$R O A$ & 1 & \\
\hline$R E D$ & -0.09 & 1 \\
\hline
\end{tabular}

Source: Eviews 9

Regression Analysis

The research work also uses regression analysis to test the relationship between the reinsurance dependence (RED) and profitability (ROA) by using Eviews 9 Statistical Software Package 
Table 3: Profitability Model of Random Effect regression result.

Cross-section random effects test equation:

Dependent Variable: ROA

Method: Panel Least Squares

Date: 08/31/17 Time: 23:50

Sample: 20112016

Periods included: 6

Cross-sections included: 12

Total panel (balanced) observations: 72

\begin{tabular}{|l|l|l|l|l|}
\hline Variable & Coefficient & Std. Error & t-Statistic & Prob. \\
\hline C & $\mathbf{0 . 0 6 9 5 4 7}$ & $\mathbf{0 . 0 5 9 2 9 4}$ & $\mathbf{- 1 . 1 7 2 9 1 0}$ & $\mathbf{0 . 2 4 5 2}$ \\
\hline RED & $\mathbf{- 0 . 0 4 2 9 0 3}$ & $\mathbf{0 . 0 1 0 2 2 7}$ & $\mathbf{- 3 . 0 3 4 0 5}$ & $\mathbf{0 . 0 0 0 9 * * *}$ \\
\hline R-squared & $\mathbf{0 . 7 8 3 1 5 6}$ & \\
\hline Adjusted R-squared & $\mathbf{0 . 7 3 9 2 3 7}$ & \\
\hline Prob. (F-statistic) & $\mathbf{0 . 0 0 0 3 8 3}$ & \\
\hline Durbin Watson stat & $\mathbf{1 . 7 9 8 2 0 8}$ & \\
\hline
\end{tabular}

$* * *, * *$, and $*$ denote significance at $1 \%, 5 \%$, and $10 \%$ levels, respectively

Source: Financial statement of sampled non-life insurers and own computation through output of E-views 9.

As exhibited in table 4.7 the beta value (coefficient) of reinsurance dependence which measured by the ratio of premiums ceded in reinsurance to total asset was statistically significant and has negative impact on profitability which measured by ROA at $1 \%$ significance level $(\mathrm{p}$-value $=0.0009)$ which implies that increase reinsurance dependence on the Property and Causality insurers will leads to decline profitability negatively in Ethiopian Property and Causality insurance companies. It indicates the potential exposure of insurance companies to the collectability problems of reinsurance. This finding created controversy with that of the previous studies conducted in Ethiopia as well as in other jurisdictions. For instance, Boyjoo and Ramesh (2017) in Mauritius, Asrat and Tesfahun (2016) and Demis (2016) in Ethiopian, found negative and insignificant relationship between profitability and reinsurance dependence among Property and Causality insurance companies which implies that reinsurance dependence is not prime determinant of profitability in Mauritius and in Ethiopia during they conduct their studies. In contrary to that, Lee (2014) and Iqbal et. al., (2013) found a significant and negative relationship between reinsurance dependence and insurance profits. Furthermore, Cummins et al., 2012; Iqbal et.al., 2013 and Lee (2014) states that reinsurance utilization improves the performance of the firm while the reinsurance dependence and exposure of reinsurance reduce its performance measured by ROA which is in line with the finding of the current study. When the company reduce the amount of premium ceded to the insurers it will help the insurers to increase their profitability and vice-versa.

\section{Conclusion and Recommendation}

To conclude, it can be argued profitability of the Property and Causality insurance companies are not well understood in the current different finance literatures in both developed and less developed countries because profitability determinants are not the same from one country to another country; even from one sector to another sectors. Particularly, the basic question is what is the perceived nexus between reinsurance dependency and profitability for Property and Causality insurance business? To answer this, a large body of research has attempted to identify these factors; however, the findings of prior empirical studies have provided varying evidence related to the impact of those factors on insurance companies' profitability measured by Return on Asset (ROA). In order to conduct the empirical analysis, only one dependent and independent variable, profitability (ROA) and reinsurance dependency were used respectively.

In conclusion, the major finding of the study indicates that reinsurance dependency are highly influence the profitability of Property and Causality insurance companies' profitability in Ethiopia context. The finding of the study is also confirmed that, Market Structure theory particularly Structural Conduct Performance and the Modern Portfolio theory are relevant theory in Ethiopian Property and Causality insurance companies. Generally, the analyses and discussion indicated that higher amount of reinsurance dependency were significantly leads to low amount of profitability Based on the result, it the study noted that when the amount of premium ceded is reduced it will help the insurers to increase their profitability. In context to this, the study recommends that the management of Property and Causality insurance business should give high attention on the reinsurance dependency since it is negatively affect the profitability of Property and Causality insurance business operating in Ethiopia.

\section{Reference}

Abebaw, K. 2014. 'Assessment of the Performance of Ethiopian Financial Sector and Economic Environment', Global Journal of Management and Business Research, 14(2), Pp.1-7. 
Adebowale, A.O. and Adebayo, O.M., 2018. Reinsurance Utilisation and Performance of Non Life Business in The Nigerian Insurance Industry: A Mixed Methods Approach. The Journal of Risk Management and Insurance, 22(2), pp.18-30.

Aduloju, S.A. and Ajemunigbohun, S.S., 2017. Reinsurance and performance of the ceding companies: the Nigerian insurance industry experience. Economics and Business, 31(1), pp.19-29.

Asrat, L and Tesfahun,T. 2016. 'Determinants of profitability in private insurance company's in Ethiopia', Journal of Poverty, Investment and Development, Vol.26, Pp.85-92

Borlea, N.S.and Achim, M.V. 2010. 'Business performances: between profitability, return and Growth', Annals of the University of Craiova, Economic Sciences Series, 2(38), Pp. 10-22.

Boyjoo, T and Ramesh, V. 2017. 'A study on factors influencing performance of general insurance companies in Mauritius: An empirical evidence', International Journal of Conceptions on Management and Social Sciences, 5 (1), Pp. 23-19

Brainard, L. 2008. What is the role of insurance in economic development (Zurich? Government? Industry Affairs thought leadership series)?

Bressan, S., 2018. The impact of reinsurance for insurance companies.

Burca, M.A and Batrinca, G. 2014. 'The determinants of financial performance in the Romanian insurance market', International Journal of Academic Research in Accounting, Finance and Management Sciences, 4(1), Pp.299308.

Curak, M, Loncar, S and Poposki, K. 2009. 'Insurance sector development and economic Growth in transition countries', International Research Journal of Finance and Economics, 34(3), Pp.29-41.

Daare, J.W. 2016. 'Determinants of non-life insurance companies' profitability: An empirical study in India', Internal journal of innovative research and advanced studies, 3(13), Pp.6-11

Datu, N., 2016. How do insurer specific indicators and macroeconomic factors affect the profitability of insurance business. A Panel Data Analysis on the Philippine Non-Life Insurnce Market A paper presented at the DLSU Research Congress, Vol.4, Pp. 7-9.

Demis, H. 2016. 'Macroeconomic and firm specific determinants of profitability of insurance industry in Ethiopia', Global Journal of Management and Business Research, 6(7).

$\begin{array}{lll}\text { Ethiopia-African } \quad \text { Economic } \quad \text { Outlook,2016. } & \text { ht/www.et.undp.org/content/ }\end{array}$ ethiopia/en/home/library/poverty/2016.html.

Geiger, M.T and Moller, L.C. 2015. Fourth Ethiopia economic update: overcoming constraints in the manufacturing sector. Washington, DC: World Bank Group. Web: http://documents.world bank. org/curated/en/2015/07/24756616/fourth ethiopia-economic-update-overcoming constraints- manufacturingsector.

IFRS 4-Insurance Contracts,Online, Available: https://www.iasplus.com/en/standards/ifrs/ifrs4

Iqbal, H.T. and Rehman, M.U., 2014. Reinsurance analysis with respect to its impact on the performance: evidence from non-life insurers in Pakistan', International Journal of finance (8), Pp.90-113.

Jovovic,M, Paunovic, B and Kocovic, J. 2014.'Determinant of business performance of non-life insurance business companies in Serbia', Ekonomika preduzeća, 62(7-8), Pp.367-381

Kihara, M. 2012. The Importance of Insurance its challenges and solutions.

Kozak, S. 2011. 'The determinants of profitability of non-life insurance companies' in Poland during integration with the European Financial System', Electronic Journal of Polish Agricultural Universities, 14(1), Pp.01

Kugler, M. and Ofoghi, R., 2005, September. Does insurance promote economic growth? Evidence from the UK. In Money Macro and Finance (MMF) Research Group Conference (Vol. 8).

Lee, H.H. and Lee, Y.C. 2012. 'An analysis of reinsurance and firm performance: Evidence from the Taiwan property- liability insurance industry', The Geneva Papers on Risk and Insurance Issues and Practice, 37(3), Pp.467-484.

Lee,Y.C 2014. 'The effect firm specific factors and macroeconomics on profitability in Taiwanese propertyliability insurance industry in Taiwan', Asian Economic and Financial Review, 4(5), Pp.681.

Mazviona, W.T, Dube, M and Sakahuhwa,T. 2017. 'An Analysis of factors affecting the performance of insurance companies in Zimbabwe' Journal of Finance and Investment Analysis, 6(1),Pp.1-2.

Ministry of Finance and Economic Development (MoFED), from 2011 to 2016, report

Moro, O and Anderloni, L. 2014. 'Non-life insurance economic performances: an empirical investigation', Journal of Economics and Management, 18, Pp.159-177

Mwangi, M. and Murigu,W.J. 2015. The determinants of financial performance in general insurance companies in Kenya, European Scientific Journal, 11(1), Pp.288-297

National Bank of Ethiopia (NBE), from 2011 to 2016, report.

National Bank of Ethiopia (NBE), from 2017, Quarterly bulletin report.

Pavic T.K and Pervan, M. 2010. 'Determinants of insurance companies' profitability in Croatia', The Business Review, Cambridge, 16(1), Pp.209-216. 
Pervan. M and Kramaric, P.T. 2012. 'Effects of market share and diversification on nonlife insurers' performance', World Academy of Science, Engineering and Technology, International Journal of Social, Behavioral, Educational, Economic, Business and Industrial Engineering, 6(1), Pp.73-80.

Saunders, N, Lewis, P and Thornhill, A. 2016. Research method for business student, 4th Edition, Pearson Education.

Sidhu, A.S. and Verma, N., 2017. Unveiling the Factors Affecting Profitability of Reinsurance Companies. Management and Labour Studies, 42(3), pp.190-204.

\section{Notes}

Table 0.1: Summary of descriptive statistics

\begin{tabular}{|l|l|l|l|l|l|l|}
\hline & Mean & Median & Maximum & Minimum & Std. Dev & Observations \\
\hline ROA & 0.10 & 0.11 & 0.22 & -0.06 & 0.05 & 72 \\
\hline RED & 0.68 & 0.41 & 3.88 & 0.01 & 0.69 & 72 \\
\hline
\end{tabular}

Source: Output of Eviews 9

Table 0.2: Profitability Model of Random Effect regression result.

\begin{tabular}{|l|l|l|l|l|}
\hline Variable & Coefficient & Std. Error & t-Statistic & Prob. \\
\hline C & 0.069547 & 0.059294 & -1.172910 & 0.2452 \\
\hline RED & -0.042903 & 0.010227 & -3.03405 & $0.0009 * * *$ \\
\hline R-squared & 0.783156 & \\
\hline Adjusted R-squared & 0.739237 & \\
\hline Prob. (F-statistic) & 0.000383 & \\
\hline Durbin Watson stat & 1.798208 & \\
\hline
\end{tabular}

$* * *, * *$, and $*$ denote significance at $1 \%, 5 \%$, and $10 \%$ levels, respectively

Source: Own computation through E-views 9 software by the author for property and Causality insurance. 